\title{
Rettspolitisk mobilisering og strategisk sakførsel mot isolasjon i norske fengsler ${ }^{1}$
}

Kjersti Lohne, postdoktor, Institutt for kriminologi og rettssosiologi, Universitetet i Oslo Marte Rua, stipendiat, Institutt for kriminologi og rettssosiologi, Universitetet i Oslo

\begin{abstract}
Solitary confinement in prison and police detention has been a widespread criminal policy and human rights problem in the Scandinavian countries for decades. However, in recent years, there has been a significant legal mobilization in Norway whereby lawyers individually and collectively have challenged solitary confinement in the courts. This use of strategic litigation has been directed towards solitary confinement in police custody, remand and during imprisonment. Based on qualitative interviews and documents, we analyze the organizational and legal strategy behind this legal mobilization, along with its effects and preconditions. We find that strategic litigation by lawyers has played an important role in the struggle against solitary confinement in Norway, but that it has benefited from - and played in tandem with - a legal and political opportunity structure consisting of national as well as international actors, processes, and legal frameworks. These findings raise the question of whether lawyers and civil society can contribute in similar ways in the other Scandinavian countries.

\section{Keywords}

Legal mobilization, strategic litigation, human rights, solitary confinement, the Norwegian Lawyers' Association

Rettslig mobilisering, strategisk sakførsel, menneskerettigheter, isolasjon, Advokatforeningen
\end{abstract}

\section{Innledning}

Bruken av isolasjon i fengsel er et omfattende kriminalpolitisk og menneskerettslig problem i Danmark, Norge og Sverige. Selv om de tre skandinaviske landene ofte blir fremstilt som foregangsland innenfor både human strafferettspleie og opprettholdelsen av menneskerettigheter, har bruken av isolasjon i skandinaviske fengsler mottatt betydelig internasjonal kritikk i mer enn 25 år fra Europarådets torturforebyggingskomite (CPT) og FNs torturkomite

1. Title in English: Legal mobilization and strategic litigation against the use of solitary confinement in Norwegian prisons 
(CAT). Problemet isolasjon i skandinaviske fengsler har til tider hatt preg av å være en inngrodd - og uangripelig - praksis.

I Norge har det imidlertid de senere årene vært betydelig bevegelse på dette området. I denne artikkelen ser vi nærmere på hvordan en del av disse endringene er knyttet til rettslig mobilisering og domstolenes evne til å endre norsk forvaltningspraksis i kriminalpolitikken. Vårt fokus er på den rettspolitiske mobiliseringen mot isolasjon i politiarrest, i varetekt og under soning. Vi undersøker hvilke sosiale prosesser og strukturer som muliggjør rettspolitisk mobilisering (Epp, 2008; Gustafsson and Vinthagen, 2010) - og særlig mot isolasjon i fengsel. Formålet med artikkelen er således å bidra med innsikt i de rettspolitiske prosessene på isolasjonsfeltet i Norge, og hvordan domstoler på ulike måter er brukt som rettspolitiske verktøy for å endre forvaltningens praksis og oppnå strukturell endring. Ved å trekke på rettslig mobiliseringsteori - hvordan retten brukes på en eksplisitt og bevisst måte gjennom å påkalle formelle institusjonelle mekanismer - (for en oversikt, se Lehoucq and Taylor, 2020), viser vi hvordan den strategiske sakførselen (Block, 2011) blant forsvarsadvokater har vært todelt: På den ene siden har den bestått av å prøve spesielt egnede saker for domstolene, og på den andre siden har den bestått av å trekke inn isolasjon som tema i straffeutmålings- og fengslingsmøter. Vi viser videre hvordan disse to formene for legalstrategier har fungert i tospann med både rettslige og politiske mulighetsstrukturer (Vanhala, 2012; Meyer and Minkoff, 2004) bestående av andre nasjonale og internasjonale aktører, prosesser og rettigheter i kampen mot isolasjon.

Artikkelen består av sju deler. Neste del gir en kort beskrivelse av isolasjonsproblematikken i Skandinavia og sammenkoblingen mellom fengselsreformbevegelsen med den internasjonale menneskerettigheter. Deretter redegjør vi for rettslig mobiliseringsteori med særlig fokus på rettslige og politiske mulighetsstrukturer, før del tre beskriver metodevalg og empiriske data som artikkelens analyse baserer seg på. I del fire tar vi for oss den rettslige mobiliseringen mot isolasjon (i) i politiarrest, (ii) i varetekt og (iii) under soning. Deretter diskuterer vi hvordan den rettslige mobiliseringen har fungert i tospann med en politisk mobilisering, og viser hvordan isolasjonsdebatten i Norge på ulike måter har skapt en form for bevegelse og dynamikk hvor ulike aktører virker inn på hverandre. Avslutningsvis trekker vi trådene tilbake til Skandinavia, og spør hvordan artikkelens analyse kan danne utgangspunkt for både handling og videre forskning på rettspolitisk mobilisering og bruk av strategisk sakførsel mot isolasjon i fengsel også i de øvrige skandinaviske landene. 


\section{Isolasjon og menneskerettigheter}

Ifølge FNs definisjon av isolasjon, slik den er nedfelt i de såkalte Mandela-reglene, innebærer isolasjon at fangen er innlåst i 22 timer eller mer i døgnet uten meningsfull menneskelig kontakt. ${ }^{2}$ I praksis er isolasjon et sammensatt fenomen som kan ta mange former. Vi tar for oss isolasjon som forekommer i politiarrest, under varetektsfengsling eller soning. Disse formene for isolasjon begrunnes etter mange ulike formål, slik som ro og orden, for å hindre bevisforspillelse, eller til og med av praktiske hensyn (for en typologi, se Rua et al., 2019; Smith, 2019). Et viktig skille går mellom domstolsbesluttet og fengselsbesluttet isolasjon. Tradisjonelt sett har de skandinaviske landenes bruk av domstolsbesluttet isolasjon under varetektsfengsling fått mest oppmerksomhet, og her har det også skjedd betydelige forbedringer i Danmark og Norge over en lengre periode. Særlig i Danmark, der det oppsto en omfattende offentlig debatt om denne isolasjonsformen på slutten av 1970-tallet drevet fram i regi av «lsolasjonsgruppen» i Dansk Retspolitisk Forening og holdt gående i årtier (se bl.a. Koch et al., 2003; Smith and Koch, 2019: 126130). Kritisk oppmerksomhet i den danske offentligheten rundt isolasjon etter Retsplejeloven har vært avgjørende for at denne isolasjonstypen har gått ned fra over 40 prosent av alle varetektsfengslinger til et historisk lavt nivå på under 1 prosent i dag (Rua et al. 2019: 50-51). Også i Norge har bruken av fullstendig isolasjon i varetekt blitt betydelig redusert fra ca. 36 til 11 prosent av alle fengslingssaker i løpet av 15 år, og brukes i dag i om lag 1/3 av sakene der det er fare for bevisforspillelse (Rua et al., 2019: 52; Horn, 2017: 149-151). Endringene skyldes i stor grad endringer i straffeprosessloven i 2002, da man delvis adopterte danske regler og innførte tydeligere domstolskontroll og krav til begrunnelse, med mål om å begrense isolasjon under varetekt og unngå framtidig kritikk fra menneskerettslige organer (Horn, 2017: 143-148).

I Norge har det i de senere årene vært «et historisk taktskrifte i debatten om fengselsbesluttet isolasjon» (Rua and Smith, 2019a: 7). Det er i all hovedsak denne formen for isolasjon som har vært gjenstand for en betydelig rettspolitisk mobilisering, og som vil være hovedtema for analysen i denne artikkelen. Mobiliseringen har rettet seg mot isolasjon etter klare fengselsvedtak, men også mot såkalt de facto eller faktisk isolasjon, der isolasjonen ikke er besluttet i vedtak hjemlet i lov, men skjer som en følge av praktiske hensyn eller lokale innlåsningsregimer. Faktisk isolasjon fikk særlig oppmerksomhet i den norske offentligheten fra 2018, da både CAT og CPT uttrykte bekymring for praksisen i forbindelse med sine Norges-besøk (CAT, 2018; CPT, 2019). ${ }^{3}$ Denne formen for isolasjon er avdekket i flere fengsler, blant dem i Oslo fengsel, der Sivilombudsmannen fikk bekreftet Kriminalomsorgsdirektoratets egne

2. The Mandela Rules (2015, rule 44.)

3. Bekymring for faktisk isolasjon ble også meldt til Stortinget allerede i 2016 (i Nasjonal institusjon for menneskerettigheter, 2016: 16) 
målinger som viste at den store majoriteten var innlåst i mer enn 16 timer i døgnet, mellom 21 og 45 prosent var isolert i minst 22 timer i døgnet - og opp mot halvparten var isolert i helgene (Sivilombudsmannen, 2019: 23). Flertallet av disse satt isolerte uten begrunnelse og vedtak. Mange var dermed ikke synlige i statistikken over isolerte, og de kunne heller ikke påklage eller anke isolasjonen (Sivilombudsmannen, 2019: 37-38).

Sivilombudsmannen er oppnevnt av Stortinget med det formål å ivareta individers rettigheter i møte med forvaltningen. Fra 2014 fikk ombudsmannen også et særskilt ansvar for å holde oppsyn med hvordan rettighetene til frihetsberøvede ivaretas, og for å forebygge tortur og annen umenneskelig eller nedverdigende behandling eller straff. ${ }^{4}$ Mandatet ble gitt av Stortinget da Norge sluttet seg til Tilleggsprotokollen av 2002 til FNs torturkonvensjon (OPCAT) i 2013, som pålegger statene å opprette et nasjonalt forebyggingsorgan («national preventive mechanism»). Sivilombudsmannen har etter dette foretatt regelmessige besøk til steder hvor mennesker er fratatt friheten, hvorpå enheten kommer med anbefalinger for å forebygge tortur og umenneskelig behandling på bakgrunn av disse besøkene. ${ }^{5}$ Sivilombudsmannens rapporter er dermed en viktig kilde til kunnskap om isolasjon i norske fengsler. I tillegg til å gi anslag av omfanget av isolasjon - det påpekes at myndighetene ikke har tilstrekkelig oversikt over isolasjonsbruken i fengslene - dokumenterer rapportene også skadevirkningen av isolasjon, som for eksempel selvskading, forhøyet selvmordsrisiko, utvikling av alvorlig psykiske lidelser, økt aggresjon og svekket impulskontroll (Silvilombudsmannen, 2019). Således danner Sivilombudsmannens relativt nye og fremtredende rolle på feltet et viktig bakteppe for å forstå den økte rettspolitiske mobiliseringen mot isolasjon i Norge, og som vi vil komme tilbake til.

Like fullt er det viktig å anerkjenne en historisk kontinuitet i det rettspolitiske arbeidet. Rettspolitisk mobilisering i Norge er langt fra noe nytt. ${ }^{6}$ Heller ikke kritikken av isolasjon, som går langt tilbake i tid også i Norge (Mathiesen, 2011: 20). Dette gjelder også den tette sammenkoblingen mellom akademikere og advokater i det rettspolitiske engasjementet i arbeidet mot isolasjon. Norsk forening for kriminalreform (KROM) har vært en sentral pådriver for isolasjonskritikk siden 1970-tallet, men har særlig de senere årene i økende grad spilt en betydelig rolle som møtepunkt for nyere generasjoner av aktivister. ${ }^{7}$ Som en arena for mobilisering og organisering av ulike miljøer og enkeltpersoner,

4. https://www.sivilombudsmannen.no

5. https://www.sivilombudsmannen.no/torturforebygging/mandat/

6. Rettspolitisk mobilisering har vært fremtredende i det kritiske juss-og rettssosiologiske miljøet ved Universitetet i Oslo siden 1970-tallet, blant annet gjennom rettshjelpsorganisasjonene JussBuss (1971) og JURK (1974). Et veiskille for en voksende rettsbevissthet var også kampen mot utbyggingen av Alta-Kautokeino-vassdraget på 1970- og 80-tallet.

7. Isolasjon har vært et fornyet gjengangertema på programmet særlig siden 2014, da Skandinavisk isolasjonsnettverk ble lansert på KROMs årlige kriminalpolitiske konferanse. 
videreføres dermed det engasjementet og aktivismen både fra akademikere og jurister som har preget norsk rettspolitikk. ${ }^{8}$

Imidlertid synes den aktive bruken av domstoler som rettspolitisk strategi for å endre norsk forvaltningspraksis å være av nyere dato. Et sentralt argument i denne artikkelen er at det er i møte med den internasjonale menneskerettighetsbevegelsen at reformbevegelsen har fătt et nytt momentum (se også Lobel and Smith, 2019a). På området isolasjon i fengsel, har det de siste 15 årene foregått en betydelig utvikling på det internasjonale menneskerettighetsfeltet (Lobel and Smith, 2019b). ${ }^{9}$ Parallelt med revisjonen av FNs standard minimumsregler for fangebehandling i de såkalte Mandelareglene fra 2015, har isolasjon i fengsel også fått et betydelig sterkere fokus i Europarådet og dens torturovervåkingskomite, sist vist i revisjonen av De europeiske fengselsreglene i 2020. Disse minimumsstandardene har lik status, og danner grunnlag for Sivilombudsmannens vurderinger av fengslenes praksis nasjonalt. Det er rapporter fra komiteene i FN og Europarådet - CAT og CPT - som utgjør den internasjonale kritikken som Norge får (se generelt Cliquennois and De Suremain, 2017). Internasjonale menneskerettigheter - og deres implementering i norsk rett - utgjør dermed en vesentlig del av hva som muliggjør rettslig mobilisering mot isolasjon i fengsel, nettopp ved å tilrettelegge for en rettslig mulighetsstruktur (Vanhala, 2012) av tilgjengelige rettsregler for å overprøve forvaltningens praksis. Dette siste er av avgjørende betydning, nettopp fordi det kan være langt mellom det normative rammeverket som menneskerettighetene forfekter, og implementeringen og realiseringen av disse rettighetene i nasjonal lovgivning og praksis. At en jobber for et sterkere individuelt rettsvern mot isolasjon gjennom bruk av domstolene er derfor ikke et unikt tilfelle i Norge, men kan sees som en del av en større internasjonal trend. Særlig i USA og i Canada ser vi at kampen mot isolasjon utspiller seg i domstolene, hvor den også er et ledd i en lengre kamp for bedring av fengselsrettigheter gjennom strategisk sakførsel (se for eksempel Lobel, 2019; Parkes, 2017).

8. Her har Thomas Mathiesen spilt en særlig fremtredende rolle hvor han både som kritisk tenker og aktør har levert vesentlige bidrag til kunnskapen om hvordan en tenker og handler for å øke politisk handlekraft og gjennomslag i møte med repressive og undertrykkende statlig praksis - fengselsstraff spesielt - siden 1960-tallet. Særlig relevant i vår sammenheng er hans advarsler mot ukritisk rettsoptimisme.

9. Også her har endringene blitt drevet fram gjennom en allianse av forskere og aktivister. Peter Scharff Smith, professor i rettssosiologi ved Universitetet i Oslo, var blant pådriverne for et ekspertmøte om isolasjon i fengsel i lstanbul i 2007 for å fremme gamle og lage nye standarder for bruken av isolasjon basert på forskning (Smith, 2008). Sammen med 23 andre tortureksperter forfattet han Istanbul-erklæringen om bruk og effekter av isolasjon i fengsel (The Istanbul Statement, 2007). Manfred Nowak, FNs spesialrapportør på området tortur, var også blant deltagerne. Både Nowak, og hans etterfølger i FN, Juan Mendez, fremmet Istanbul-erklæringen i ulike fora i FN - til den grad at FN reviderte og betydelig styrket sine fengselsregler i 2015 i tråd med erklæringen, og som i dag er kjent som Mandela-reglene. 


\section{Rettslig mobiliseringsteori}

«Rettslig mobilisering» henviser til hvordan retten brukes på en eksplisitt og bevisst måte gjennom å påkalle formelle institusjonelle mekanismer (Lehoucq and Taylor, 2020; se også McCann, 2006; Vanhala, 2011). Slik sett har studier av rettslig mobilisering mye til felles med studier av individers rettslige bevissthet («legal consciousness») - den implisitte, ikke-artikulerte bruken av retten for å gi mening til hendelser (Silbey and Ewick, 2000), og rettslig innramming, eller framing («legal framing») - den bevisste og eksplisitte bruken av retten for å gi mening til hendelser (Lehoucq and Taylor, 2020). Innen rettslig mobiliseringsteori er man opptatt av aktører - både individuelle og kollektive - så vel som rettslige og politiske strukturer som muliggjør, eller motvirker, rettslig mobilisering. Videre henviser rettslig mobilisering til et kontinuum av handlinger: fra handlinger som beskriver hvordan rettens institusjoner, normer, diskurser og symboler påkalles for å fremsette krav og/eller sosial endring, til en snevrere tolkning av rettslig mobilisering som strategisk sakførsel som rettspolitisk strategi (Epp, 1998).

Strategisk sakførsel innebærer strategisk utvelgelse og føring av saker for nasjonale, regionale, eller internasjonale domstoler, med den hensikt at sakene også får virkninger utover den konkrete saken (Block, 2011). Strategien er i stor grad forbundet med de angloamerikanske rettssystemene, hvor strategisk sakførsel lenge har vært en utbredt praksis blant sosiale bevegelser for å skape strukturell endring gjennom en styrking av individuelle rettigheter (Epp, 1998; Epp, 2008). Ettersom prejudikater har en langt sterkere stilling $\mathrm{i}$ «common law»-jurisdiksjoner som de angloamerikanske enn hva som er tilfellet i de nordiske rettssystemene, blir dette regnet som en forklaring både på den utbredte praktiseringen av strategisk sakførsel i USA og Storbritannia, og på den relativt beskjedne praksisen blant jurister og sosiale bevegelser i Skandinavia (Block, 2011; Langford et al., 2019). Det må med andre ord være en rettslig mulighetsstruktur til stede for rettslig mobilisering gjennom strategisk sakførsel. Forskningen på dette området er interessert i hvilke praktiske og strategiske forhold som spiller inn for om og hvordan aktører beslutter å mobilisere retten for å nå sine mål. For eksempel er det grunnleggende for strategisk sakførsel at det er snakk om et rettslig spørsmål, at dette spørsmålet kan prøves for domstolene, og at aktørene har tilgang til domstolene. ${ }^{10}$ Dette betyr at det kan være vanskelig å prøve isolasjon under domssoning for retten, nettopp fordi den isolerte har dårligere tilgang til advokat og domstoler enn under fengslingsmøter og straffesaker. Materiell støtte i form av finansielle midler og andre ressurser er også vesentlig, nettopp fordi strategisk sakførsel kan være langvarig, dyrt og risikofylt (Epp, 1998). Organisasjoner - som Advokatforeningen - med

10. Tvisteloven regulerer behandlingen av sivile saker i Norge, inkludert kravene til rettslig interesse for å anlegge sak for domstolene. 
sterke organisatoriske ressurser inkludert juridisk ekspertise og nettverk, vil derfor ha en langt bedre sjanse til å utnytte rettslige muligheter (Börzel, 2006). Videre fremheves det i denne litteraturen betydningen av dommere, og hvorvidt de - og rettssystemet generelt - er åpne for de sosiale og politiske målene som søkes oppnådd gjennom strategisk sakførsel. Her trekkes det også på en rik litteratur om politiske mulighetsstrukturer, som i stedet for utelukkende å se på hvorvidt rettssystemet er mottakelig for sosial endring også ser på hvorvidt forvaltningen er tilgjengelig for eksterne aktørers mål og midler - både for spesifikke saker og på generell basis (Meyer and Minkoff, 2004). Dette er fordi individuelle og kollektive aktører, slik som sosiale bevegelser, sjelden kun bruker én strategi for å oppnå sine mål, og fordi rettsligmobilisering ofte tar - slik vi vil vise - mange former.

I norsk rettssosiologi har spørsmålet om man ved hjelp av rettslig styring kan skape større utjevning i levevilkår og maktforhold i samfunnet vært en sentral problemstilling (Mathiesen, 2001). Men i stedet for en ukritisk eller rettsoptimistisk oppfatning - som strategisk sakførsel gjerne tolkes som et uttrykk for - fremhever Mathiesen (2001) betydningen av en rettskritisk oppfatning som fordrer en gjennomtenkt og forsiktig bruk av legalstrategier. I vurderingen av strategisk sakførsel som virkemiddel er det ifølge ham særlig tre hensyn å ta: For det første bør man velge rett tidspunkt, politisk. Som vi vil komme tilbake til, opererer verken retten, domstolene eller rettens aktører i sosiale vakuum - de er en del av samfunnet, og er således påvirket av skiftende normer og opinionsklima også utenfor domstolens fire vegger. For det andre bør man vurdere konsekvensene av et tap. Hva gjelder sivile søksmål knytter dette seg særlig til saksomkostninger og hva et tap helt direkte innebærer for klienten saken føres på vegne av, men et tap kan også bli spikeren i kista for den politiske saken. Dette henger sammen med et tredje element som bør tas med i beregningen, nemlig fordelene og ulempene ved at saken og dens problemstilling rettsliggjøres. Som Christie så spissfindig observerte, bærer rettsliggjøringen med seg en form for «konflikttyveri» som ikke bare «frarøver» konflikten fra dem saken gjelder, men også reduserer konflikten til en ny, forenklet og juridisk argumentasjon (Christie, 1977). Slike dynamikker og utfall er det dermed all grunn til å ta med i vurderingen av legalstrategier - og særlig strategisk sakførsel - i kampen mot isolasjon. Imidlertid kan jurister, som Mathiesen (2001) fremhever, ved et slikt rettskritisk, evaluerende perspektiv bidra til å hjelpe svakerestilte eller underordnede grupper i samfunnet.

Formålet med denne artikkelen er å undersøke hvordan strategisk sakførsel bidrar til den rettspolitiske kampen mot isolasjon i Norge. I det følgende vil vi redegjøre for studiens datagrunnlag og analyse, før vi beskriver den rettslige mobiliseringen i form av strategisk sakførsel mot isolasjon i politiarrest, i varetekt, og under soning. Deretter vil vi, med utgangspunkt i gjeldende forskning, reflektere over betingelser og prosesser som medvirker til - eller motvirker - rettslig mobilisering, og vise hvordan rettslige fremskritt i domsto- 
lene også er avhengige av parallelle politiske prosesser som danner en politisk mulighetsstruktur for rettsutviklingen. Avslutningsvis stiller vi spørsmålet om hvor kampen mot isolasjon går videre.

\section{Metode}

Denne artikkelen springer ut av et nordisk forskningsprosjekt om domstolenes rolle i utvidelsen av individuelle rettigheter i Skandinavia, og om sivilsamfunnets bruk av domstoler til dette formålet. Lohne har i en norsk kontekst foretatt en studie av Advokatforeningens rettspolitiske engasjement og bruk av strategisk sakførsel i norske domstoler. I alt er det foretatt 14 semistrukturerte intervjuer med advokater tilknyttet Advokatforeningen hovedsakelig i Oslo, og som danner et empirisk utgangspunkt for denne artikkelen. Rua skriver doktorgrad om isolasjon i fengsel, basert på en institusjonell fengselsetnografi. Denne artikkelen bygger både på innsamlede dokumenter i materialet og hennes mer overordnede empiriske og analytiske innsikt som et resultat av fordypning i feltet som deltagende observatør over mange år. Forfatterne har foretatt en dokumentanalyse av politiske rundskriv fra Riksadvokaten og Kriminalomsorgen, samt rapporter fra Sivilombudsmannen, Røde Kors, NIM, CPT og CAT og relevante dommer. Dommene fra Advokatforeningens strategiske sakførsel på isolasjonsfeltet er uttømmende - det gjelder, som vi vil komme tilbake til, kun to saker. Per dags dato finnes det imidlertid ingen oversikt over dommene hvor forsvarsadvokater har utfordret statens bruk av isolasjon i fengslings- og straffesaker der isolasjon ikke har vært et hovedtema. Vårt formål har derimot vært å analysere domstolsbeslutninger hvor denne strategien har fungert etter hensikten. Således er det selve den rettslige mobiliseringen og dens konsekvenser vi er interesserte i, og ikke dens suksessrate som sådan.

Når det er sagt er kampen om isolasjonsbruken pågående, der et økende antall aktører og hendelser de siste årene stadig åpner for nye muligheter og vendinger. Denne artikkelen vil dermed ikke gi et fullstendig bilde av hvordan denne har utspilt seg - ikke bare fordi den er uferdig, men også fordi vårt fokus har vært på advokatenes og domstolenes rolle, framfor alle de andre fremtredende aktører på feltet. Like fullt vil vårt fokus på det rettslige sporet i denne kampen - og dens aktører - bidra til en større forståelse av de sosiale, politiske og rettslige rammene som kampen mot isolasjon utspiller seg innenfor. 


\section{Strategisk sakførsel mot isolasjon i politiarrest, i varetekt og under soning}

Glattcelledommen - isolasjon i politiarrest

Fra århundreskiftet og utover ble Advokatforeningens Forsvarergruppe ${ }^{11}$ stadig mer bekymret over bruken av isolasjon i politiarrest, som foregikk trass i betydelig og vedvarende kritikk fra CAT og CPT. Samtidig skrev juristen Thomas Horn på en doktorgrad ved Universitetet i Oslo, hvor han blant annet utarbeidet juridiske argumenter for at bruken av isolasjon i politiarrest kunne være en krenkelse av artikkel 8 i Den europeiske menneskerettskonvensjon (EMK) - retten til privatliv og familieliv (Horn, 2012). Dette til forskjell fra isolasjon som krenkelse av EMK artikkel 3 - forbudet mot tortur - som inntil da hadde vært sett på som det mest passende hjemmelsgrunnlaget for å utfordre praksisen med isolasjon i fengsel. Dette forbudet er absolutt, men til gjengjeld er terskelen for krenkelse av EMK artikkel 3 høy, noe som gjør det vanskelig å få gjennomslag i retten for at isolasjon er i strid med denne artikkelen i EMK (Horn 2012: 27). Etter et møte mellom Horn og Forsvarergruppen, begynte sistnevnte å lete etter en egnet sak for å prøve den utstrakte bruken av isolasjon i politiarrest for retten som en krenkelse av artikkel 8. I 2013 vant Frode Sulland - daværende leder for Forsvarergruppen - over staten, med Advokatforeningen som partshjelp. ${ }^{12}$ Det er verdt å merke seg at Riksadvokaten, til og med før dommen var rettskraftig sendte ut et rundskriv med henvisning til dommen, og med nye instruksjoner for å innskrenke politiets bruk av isolasjon på glattcelle i politiarresten (Horn, 2019).

\section{Isolasjon i varetekt}

De senere årene har det imidlertid også vært en økning av strategisk sakførsel mot bruken av isolasjon under varetektsopphold i fengsel. ${ }^{13}$ Etter straffeprosessloven kan retten ilegge hel eller delvis isolasjon av varetektsfengslede når det er nærliggende fare for bevisforspillelse (§ 186). Etter straffeloven gir tiden i varetekt fradrag i straffen ved fengselsdom etter fast angitte dager (såkalt varetektsfradrag, § 83 første ledd), og ytterligere fradrag for fullstendig isolasjon ilagt av retten i perioden (såkalt isolasjonsfradrag, § 83 andre ledd). Som nevnt har domstolsbesluttet isolasjon i varetekt blitt betydelig redusert gjennom 2000-tallet. Men varetektsfengslede blir også isolert av fengslet, enten hjemlet i straffegjennomføringsloven, eller uten vedtak, såkalt

11. Den norske advokatforening er en profesjons- og interesseforening for norske advokater og advokatfullmektiger. Omtrent 90 prosent av praktiserende advokater i Norge er medlem. Advokatforeningen driver rettspolitisk arbeid aktivt, se https://www.advokatforeningen.no

12. Oslo tingrett - Dom. - TOSLO-2013-103468.

13. I Norge overføres arrestanten fra politiarresten til fengsel når retten beslutter varetektsfengsling av vedkommende, og ikke til arresthus (Danmark) eller häkten (Sverige). Politiet beholder likevel ansvaret for den varetektsfengslede. 
faktisk eller de facto isolasjon. Ved siden av å være partshjelp i enkelte saker, har Advokatforeningens rolle i all hovedsak vært som en nettverksplattform for frustrerte og engasjerte forsvarsadvokater som har utfordret denne isolasjonspraksisen i retten. ${ }^{14}$ Disse begynte, i forlengelse av sin advokatrolle, å utfordre staten i retten på at isolasjon under varetekt skal gi fradrag i straff også når isolasjonen ikke var ilagt av retten.

Faktisk isolasjon har blitt løftet fram på to måter i en spesiell form for strategisk sakførsel av enkeltadvokater, noe som i 2019 førte til en serie betydningsfulle dommer. ${ }^{15}$ Blant annet besluttet Borgarting lagmannsrett sommeren 2019 å løslate en mann siktet for vold, ran, narkotikaforbrytelser og trusler - på tross av sterk gjentakelsesfare - nettopp fordi han under varetekt var blitt utsatt for omfattende isolasjon som ikke var ilagt av retten. Således var dette den første rettslige avgørelsen hvor noen løslates i etterkant av opphørt isolasjon på grunn av de alvorlige krenkelsene de har blitt utsatt for. ${ }^{16}$ I andre saker har tiltalte fått fradrag i straffen sin nettopp fordi isolasjonen har vært i strid med menneskerettighetene. Disse dommene har nå ført til at domstolene gir fradrag i straff for mer enn 22 timer innlåsning i døgnet, uavhengig om den er ilagt av retten, av fengselet eller ikke formelt besluttet i det hele tatt.

I motsetning til i Glattcellesaken var ikke isolasjon noe hovedtema i noen av disse sakene, men ble snarere trukket inn av advokater som enten en del av vurderingen av videre fengsling eller av straffutmålingen. Denne måten å drive fram domsavsigelser om isolasjon i fengsel ved å bringe den «inn bakveien», har vært en bevisst strategi fra enkelte advokater gjennom flere år i et forsøk på å få endret isolasjonsbruken.

På tampen av 2019 kom også faktisk isolasjon opp for norsk høyesterett. ${ }^{17}$ Maria Hessen Jakobsen - en av pådriverne bak strategisk sakførsel på dette området - argumenterte i Høyesterett for at faktisk isolasjon under varetektsfengsling burde gi fradrag ved straffutmålingen jf. EMK. ${ }^{18}$ Imidlertid fant Høyesterett at faktum for krenkelse ikke var tilstrekkelig bevist, men anerkjente likevel langt på vei at faktisk isolasjon skal gi fradrag i straffutmålingen. I sin begrunnelse la de også vekt på Mandela-reglene. Dommen er på denne måten et eksempel på hvordan «soft law», eller internasjonale normative menneske-

14. https://www.advokatbladet.no/isolasjon/felles-front-mot-ulovlig-isolasjon-i-fengsel/142483

15. Se blant annet Bergen tingretts dom 26. juni 2019 (TBERG-2018-153795-2), Sogn og Fjordane tingretts dom 16. juli 2019 (TSOFT-2018-164558), Bergen tingretts dom 26. juni 2019 (TBERG-2018-153795-2), Borgating lagmansretts kjennelse 2. august 2019 (LB-2019113010). Se også Norges Høyesteretts dom avsagt 7. november 2019 (HR-2019-2048-A).

16. NRK, «Fare for nye kriminelle handlinger - likevel måtte 22-åring løslates», 14. august 2019, https://www.nrk.no/norge/fare-for-nye-kriminelle-handlinger-_-likevel-matte-22-aring-loslates-1.14655131

17. Norges Høyesterett, Dom avsagt 7. November 2019, HR-2019-2048-A. Anke over Gulating lagmannsretts dom 19. mars 2019.

18. Også her bidro Advokatforeningen, samt forskere som leverte ekspertuttalelser til saken, såkalte amicus briefs. 
rettslige forpliktelser som denne fra FN, blir en del av Høyesteretts praksis, med den betydelige rettslige autoriteten som det innebærer. ${ }^{19}$

\section{Isolasjon under soning}

Advokatforeningen har også nedsatt arbeidsgruppen «Advokatforeningens isolasjonsgruppe» - en aksjons- og prosedyregruppe med formål om å prøve bruken av isolasjon under soning for retten. Blant et titalls søknader om bistand valgte Advokatforeningen å gå videre med en sak der klienten - en tidligere kvinnelig innsatt - hadde blitt utsatt for omfattede isolasjon under soning i Bredtveit kvinnefengsel, inkludert å ha rutinemessig blitt fratatt klær når fengselet plasserte henne i sikkerhetscelle og belteseng. Advokatforeningen varslet staten om søksmål for krenkelse av EMK artikkel 3 - forbudet mot tortur - og artikkel 8 - retten til privatliv og familieliv. ${ }^{20}$ Imidlertid gikk saken aldri for retten. I en rettsmekling erkjente staten brudd på torturbestemmelsen og inngikk forlik med Advokatforeningens klient. ${ }^{21}$ Forliket forplikter ikke bare staten til å arbeide for at tilsvarende ikke skjer igjen, men fastsetter også at klienten skal holde innlegg om hennes erfaringer på Kriminalomsorgens konferanse om isolasjon i 2020. Slik har man gjennom rettsforhandlinger tvunget frem ytringsrom til de isolerte selv, og således skapt nye arenaer for kunnskapsformidling, erfaringsutveksling og faglig debatt om isolasjon i fengsel, der fangeperspektivet i større grad enn før gis plass. I etterkant av forliket har sivilombudsmannen anbefallt at beltesenger afskaffes og fjernes helt fra norske fengsler (sivilombudsmannen 2020).

Advokatenes målrettede bruk av domstolene har altså tatt to hovedformer. I den ene har den rettslige mobiliseringen tatt form av en kollektiv organisering i Advokatforeningen, der målet er å endre loven gjennom å finne, forberede og prøve spesielt egnede saker for retten, og slik satse på det en kanskje kan kalle "grand hard cases», som i Glattcelledommen (isolasjon i politiarrest, 2014) og EMK3-forliket (isolasjon og bruk av tvangsmidler/belteseng på Bredtveit, 2020). Den andre strategien har hvilt på enkeltadvokaters initiativ til å ta isolasjon som tema «inn bakveien» i fengslings- eller straffesaker der isolasjon ikke er hovedtema, men snarere brukes som grunnlag

19. Det er ikke første gang FNs minimumsregler siteres i Høyesterett. I en kjennelse fra Høyesterett inntatt i Rt-2008-1764 vedrørende spørsmålet om ankenektelser må begrunnes, uttaler Høyesterett i avsnitt 81 at konvensjonstolking foretatt av FNs menneskerettskomité måtte tillegges betydelig vekt som rettskilde. Høyesterett viser til The United Nations Standard Minimum Rules for the Treatment of Prisoners (Rule 44), som Mandela-reglene er en revidering av.

20. https://www.advokatbladet.no/isolasjon-isolasjonsgruppen/saksoker-staten-for-ulovlig-isolasjon/141056

21. https://www.advokatbladet.no/advokatforeningen-isolasjon-isolasjonsgruppen/staten-erkjenner-brudd-pa-emk-artikkel-3-overfor-tidligere-innsatt/150907 
for å kreve straffereduksjon eller løslatelse. Dommene er ikke bare brukt til å få kompensasjon eller individuelle klienter ut av isolasjon, men som rettspolitiske verktøy for å stadfeste at faktisk isolasjon i fengslene er lovstridig. Denne rettspolitisk motiverte fremgangsmåten fra forsvarsadvokater kan sies å være en vellykket legalstrategisk innovasjon på dette området. Som vi nå skal vise tvang domstolenes beslutninger om lovstridig isolasjon nemlig fram konkrete endringer med rask virkning i alle norske fengsler på en måte som årtier med rettspolitisk og menneskerettslig kritikk forankret i «soft law» så langt ikke har oppnådd.

\section{Parallelle rettslige og politiske prosesser}

Etter Glattcelledommen i 2014 - før dommen var rettskraftig og mens påtalemyndighetene hadde mulighet til å anke den - sendte Riksadvokaten ut et rundskriv med nye instrukser om bruk av politiarrest til statsadvokatene og politimestrene i landet. ${ }^{22}$ Det samme synes å ha skjedd i 2019: Dette årets serie med domstolsbeslutninger ga virkninger utover de enkelte sakene, også der dommene ble avgitt i lavere rettsinstanser. Særlig synes Borgarting lagmannsretts løslatelse av en varetektsfengslet mann i Oslo i august 2019, på tross av sterk fare for gjentakelse av alvorlig kriminalitet, å ha vekket Kriminalomsorgen. Allerede en måned etter sendte Kriminalomsorgsdirektoratet (KDI) ut et rundskriv som beskriver dommene og rettsutviklingen på området, der KDI også skisserer en mulig framtid der personer som burde vært fengslet i stedet vil bli løslatt som en følge av at fengslenes isolasjonspraksis nå var funnet ulovlig. Direktoratet beordret derfor fengslene å sikre at innsatte som ikke er formelt isolert får minimum to timer i fellesskap med andre innsatte daglig, for slik å få bukt med faktisk isolasjon av praktiske grunner, og det med frist på kun tre uker. ${ }^{23}$ Med andre ord er disse dommene eksempler på hvordan rettsliggjøringen av isolasjonskampen gjenom strategisk sakførsel har endret forvaltningens praksis.

Dommen kan ikke ha kommet helt overraskende på Kriminalomsorgen. CPT har uttrykt bekymring over slik faktisk isolasjon som følge av bygningsmessige forhold og mangel på personell i sine rapporter siden så langt tilbake som 2005. ${ }^{24}$ Men det er som nevnt først de senere årene at isolasjon av praktiske hensyn, eller for å spare penger, i økende grad har vært gjenstand for oppmerksomhet og kritikk (se Rua et.al. 2019: 67-69). Sammen med CPT og CAT

22. Instruks av 24.06.14. I intervjuer med forsvarsadvokater om hva dette kan skyldes, antas det at Riksadvokaten langt på vei var enig i dommen. Politidirektoratets instruks til politimestrene kom like etter (04.07.14).

23. Innlåsningsregimer som gir to timers fellesskap eller mindre regnes imidlertid fortsatt som isolasjon av FN, slik isolasjon er definert i Mandela-reglene. Pålegget er gitt i Kriminalomsorgsdirektoratet, «Rettspraksis fra norske domstoler vedrørende isolasjon av innsatte og varetektsfradrag», 10. september 2019.

24. CPT/Inf (2006) 14, seksjon 62 og 63. 
sine besøksrapporter, har Sivilombudsmannens rapporter fra enkeltfengsler og ikke minst den særskilte meldingen om isolasjon til Stortinget, forsterket kritikken og kravene til endringer. ${ }^{25}$ To måneder før Borgarting lagmannsrett fant isolasjonen i Oslo fengsel ulovlig, stilte Sivilombudsmannen eksplisitt krav om opphør av isolasjon som ikke har hjemmel i lov i sin besøksrapport fra samme fengsel (Sivilombudsmannen, 2019: 38). Dommen falt altså ikke i et vakuum. Men hvorfor var det like fullt en dom fra en norsk domstol som skulle til for å stadfeste det forvaltningen egentlig allerede visste etter mange år med betydelig internasjonal kritikk? Som beskrevet innledningsvis, må rettigheter realiseres og håndheves, og det må finnes rettslige og politiske strukturer som muliggjør ikke bare rettslig mobilisering, men dens evne til gjennomslagskraft (Epp, 2008). Det er også forskjell på internasjonale menneskerettigheter som et normativt rammeverk («soft law») og på «hard juss»: på rettslige avgjørelser tatt av nasjonale og internasjonale domstoler. Det er forskjell på å få kritikk for gjeldende praksis, og å få den dømt ulovlig av norske domstoler. Like fullt er retten også en del av samfunnet - den inngår i et sosial og politisk landskap (Mathiesen 2001).

Det vil derfor være verdt å merke seg den særskilte politiske konteksten rundt den rettslige kampen mot isolasjon i fengsel, hvor det synes å ha vokst frem en ny type offentlighet de senere årene. Flere aktører deltar i debatten ikke bare Advokatforeningen og forsvarsadvokater, rettshjelpsorganisasjoner som JussBuss, JURK og Wayback og rettspolitiske miljøer i og rundt Norsk forening for kriminalreform (KROM), men tidligere isolerte, Sivilombudsmannen, Norges institusjon for menneskerettigheter (NIM), Røde Kors, Skandinavisk isolasjonsnettverk ${ }^{26}$ og ikke minst Kriminalomsorgen selv har bidratt til økt fokus på isolasjonsproblematikken de siste årene. Isolasjon i fengsel har også fått større oppmerksomhet i media, gjennom kritiske dokumentarer og grundige artikler om både konkrete saker og generelle aspekter ved problematikken. ${ }^{27}$ Det er med andre ord politisk bevegelse på området. Dette er bra og ikke minst nødvendig; en suksessfaktor for å bruke domstoler for strukturell endring er at det er en aktivt støttestruktur for rettslig prøving også utenfor domstolene (Epp, 1998; Epp, 2008). Ved siden av en rettslig mulighetsstruktur - at det blant annet finnes rettsregler å bruke, og at det er adgang til å bruke domstolen i det hele tatt - bidrar den delen av sivilsamfunnet som ikke selv står i retten til politiske mulighetsstrukturer som medvirker til å løfte saker opp på den politiske agendaen og i offentligheten, mobilisere til kamp der

25. Se CAT/C/NOR/CO/8, CPT/Inf (2019) 1 og Sivilombudsmannen 2019.

26. Mange av disse aktørene deltar i Skandinavisk isolasjonsnettverk, som samler profesjonelle, frivillige og organisasjoner i de skandinaviske landene. Rua var en av initiativtagerne og sitter i styringsgruppa til nettverket, som er administrert fra Institutt for kriminologi og rettssosiologi ved Universitetet i Oslo. Se www.isolation.network

27. Særlig har Brennpunkt-redaksjonen i NRK og ikke minst avisen Bergens Tidende avdekket forhold og skapt debatt gjennom virkningsfull gravejournalistikk, sistnevnte i den grad at CAT har brukt den som grunnlag i sin besøksrapport fra Norge. Se CAT/C/ $\mathrm{NOR} / \mathrm{CO} / 8$ 
den kan tas, og gjennom å synliggjøre isolasjonspraksisen og informere om dens skadevirkninger og verdimessige og menneskerettslige utfordringer. Det at rettighetspolitikk i domstolen støttes av en aktiv reformbevegelse - av aktivister, fanger, engasjerte yrkesutøvere, forskere, borgere - er helt vesentlig når det skjer, men slike bevegelser kan også være en forutsetning for at slike strategier i det hele tatt tas i bruk. Sosiale bevegelser har nemlig også spilt en rolle i nettopp å oppmuntre advokatene til å løfte isolasjonsspørsmålet på arenaer der de virker til daglig, ifølge advokatene selv. Blant annet hevder en av de mest sentrale forsvarsadvokatene på området at strategien med å «trekke isolasjon inn bakveien» var et direkte resultat av lanseringen av Skandinavisk isolasjonsnettverk i forbindelse med en debatt om isolasjon på KROM-konferansen i 2014. Strategien ble tatt i bruk fra 2016, men det gikk flere år før den ga resultater, men da i flere ulike domstoler spredt rundt i Norge gjennom 2019. Det var nettopp i disse årene at den kritiske debatten rundt isolasjon skjøt fart i Norge, noe man kan anta også har påvirket domstolenes forståelse av fenomenet. Rettsutviklingen er avhengig av slike kulturelle endringer. Dette er vekselvirkingen mellom retten og samfunnet som skaper, vel, både retten og samfunnet (Mathiesen, 2001).

Rettsliggjøringen er altså en av flere parallelle prosesser i det politiske arbeidet mot isolasjon. Den rettslige utviklingen sammenfaller med politiske forhold i noe som vitner om en dynamikk hvor prosesser bekrefter hverandre og driver hverandre videre. Beskrivelser av fengslenes praksis i Sivilombudsmannens rapporter har åpnet for en ny offentlighet rundt isolasjon, og dermed allmenn kunnskapsheving og økt oppmerksomhet både i den medierte offentligheten og internt i Kriminalomsorgen på den ene siden. På den andre siden styrker rapportene den rettslige argumentasjonen gjennom å vurdere denne praksisen opp mot internasjonale menneskerettighetsstandarder, og det kan også, i grunn, virke som om forvaltningen - Riksadvokaten og Kriminalomsorgen - har respondert ganske umiddelbart på dommene som stadfester krenkelser som følge av isolasjon. ${ }^{28}$

\section{Hvor går kampen i dag?}

I Norge er legalstrategien på isolasjonsområdet blitt ført gjennom et samarbeid mellom forskere, engasjerte forsvarsadvokater og Advokatforeningen. Både sakene sistnevnte har anlagt mot staten for å løfte isolasjon som tema generelt, og enkeltstående advokaters taktikk med å få inn isolasjon som tema i andre saker, har gitt domsavsigelser som igjen har endret praksis i både politiet og fengselsvesenet. Dette hadde ikke vært mulig uten utviklingen av menneskerettighetene og annen «soft law» på området internasjonalt, der standardene er styrket markant i etterkant av den avgjørende

28. For en beskrivelse av tilsvarende dynamiske politiske og rettslige prosesser på isolasjonsfeltet i USA, se Fettig and Fathi (2019). 
Istanbul-erklæringen om isolasjonsfengsling fra 2007 (se Rua and Smith, 2019b: 32-34). Kritikken av norsk isolasjonspraksis som sprang ut av slike internasjonale retningslinjer fikk først kraft i Norge ved å bli aktualisert i offentligheten gjennom debatt og pressedekning, men ikke minst gjennom at den nasjonale overvåkningsmekanismen hos Sivilombudsmannen har gått konkret til verks og målt slike internasjonale standarder opp mot praksis i fengslene. Sist har saken blitt løftet opp på politisk nivå særlig gjennom Sivilombudsmannens særskilte melding til Stortinget, som igjen inviterte en rekke organisasjoner foruten Kriminalomsorgen selv til offentlig høring om isolasjon i januar 2020.

Kriminalomsorgen har i dag isolasjon på prioriteringslisten, noe som blant annet viser seg i tiltaksplaner for å redusere isolasjon, initiativer til forskning, samt økt kunnskap om isolasjonsforebygging og skadereduksjon gjennom innføring av informasjonsmateriell i fengslene, ${ }^{29}$ konferanser og kurs, samt utarbeidelsen av et bachelor-emne om isolasjon i betjentutdanningen i samarbeid med isolasjonskritiske aktører. På tross av at det ennå ikke er kommet noen politiske signaler om økte budsjetter til bedre bemanning, har KDI igangsatt prosesser for å redusere bruk av isolasjon innen gjeldende budsjettrammer. Kriminalomsorgens region øst har hatt en høringsprosess om isolasjon hvor flere av de sentrale aktørene behandlet i denne artikkelen har vært involvert, deriblant Advokatforeningen, Sivilombudsmannen, Norsk institusjon for menneskerettigheter (NIM) og Røde Kors. Her har flere forslag til reduksjon av isolasjon innenfor gjeldende budsjett blitt diskutert, i tillegg til forslag til lovendringer på området.

Hva gjelder Advokatforeningen, er deres «isolasjonsgruppe» stadig fungerende, og de tar fortsatt imot forslag til saker som kan egne seg for prøving i retten. De presiserer også i sine innspill til Kriminalomsorgens region østs høring om forebygging og reduksjon av isolasjon at Straffegjennomføringsloven bør revideres og at endringene ikke bare kan komme «på retningslinjenivå». ${ }^{30}$ Justis- og beredskapsdepartementet har varslet at de vil komme med forslag om lovendringer til Stortinget som kan bidra til å redusere bruken av isolasjon. ${ }^{31}$

Isolasjon er fremdeles et problem i norske fengsler, og det er for tidlig å si hvilke overgripende endringer de siste års debatter og rettssaker vil få i praksis. Imidlertid rettes det betydelig mer oppmerksomhet mot problemene knyttet til isolasjon i dag enn tidligere, og flere endringer er på trappene - til det bedre, vil mange mene. Men hva med de øvrige skandinaviske søsterlandene, kan den forsiktige entusiasmen på vegne av de isolerte i Norge overføres til Sverige og Danmark? Disse landene mottar også overveiende internasjonal kritikk, men

29. https://www.jus.uio.no/ikrs/forskning/aktuelle-saker/2019/isolert.html

30. Advokatforeningen, Advokatforeningens innspill til Kriminalomsorgen region østs høringsmøte om forebygging og reduksjon av isolasjon.

31. https://www.advokatbladet.no/isolasjon-statsbudsjettet-2021/vil-bevilge-118-millioner-til-a-forebygge-isolasjon-i-fengsel/154523 
enn så lenge ser det ikke ut til å være en tilsvarende rettslig mobilisering i våre naboland. Med tanke på både de rettslige og politiske mulighetsstrukturene for bruk av legalstrategi som vi har sett i Norge, ligger derimot mye til rette for at isolasjonskampen også kan føres i svenske og danske domstoler.

Imidlertid er isolasjon et komplekst fenomen som også er sårbart for politiske tilstander og endringer på godt og vondt. I Sverige ligger bruken av isolasjon, også av barn og særlig i varetekt, på et rutinemessig og særdeles høyt nivå. Isolasjonen har pågått med uforminsket styrke på tross av årtier med sterk og tiltakende kritikk fra internasjonale organer (Rua m.fl., 2019: 48). På tross av at det svenske Advokatsamfundet har vært en høylytt kritiker av isolasjon i varetekt, for eksempel gjennom aktiv deltagelse i media, offentlige høringssvar m.m, har de (ennå) ikke engasjert seg i strategisk sakførsel. Kanskje det er nettopp derfor vi så langt ikke har sett en tilsvarende nedgang i bruk av isolasjon i Sverige? I Danmark har som nevnt bruken av isolasjon i varetekt lenge vært anerkjent som problematisk, mye takket være arbeidet mot nettopp denne isolasjonsformen til Isolationsgruppen fra 1970-tallet. På den andre siden har samme land stått for en eksplosiv vekst i bruk av isolasjon som disiplinærtiltak (såkalt «strafcelle») i de senere årene, som en følge av politisk bestemte krav til fengslene om å straffe selv mindre disiplinærbrudd med isolasjon (Engbo, 2019; Kessing, 2019). Ifølge blant andre jurist og mangeårige fengselsleder Hans Jørgen Engbo, har det politiske nivået slik gjort isolasjon til et rettspolitisk instrument, og det med svært uheldige resultater (Engbo 2019: 226-227). Denne formen for isolasjon under soning er, muligens, vanskeligere å anføre foran domstoler. I det minste byr det på andre rettslige utfordringer.

Kontaktoplysninger

Kjersti Lohne: kjersti.lohne@jus.uio.no

Marte Rua: marte.rua@jus.uio.no

\section{Litteratur}

Block Ø. (2011) Strategisk sakførsel som politisk påvirkning. Kritisk Juss 37: 62-68.

Börzel TA. (2006) Participation Through Law Enforcement:The Case of the European Union. Comparative Political Studies 39: 128-152. https://doi.org/10.1177/0010414005283220

CAT, The Committe Against Torture (2018) Concluding observations on the 8th periodic report of Norway, CAT/C/NOR/CO/8. digitallibrary.un.org/record/1629053

Christie N. (1977) Conflicts as property. British Journal of Criminology 17: 1. https://doi.org/10.1093/oxfordjournals.bjc.a046783

Cliquennois G. and De Suremain H. (2017) Monitoring Penal Policy in Europe: Routledge. https://doi.org/10.4324/9781315542034

CPT European Committee for the Prevention of Torture and Inhuman or Degrading Treatment or Punishment (2019) Report to the Norwegian Government on the visit to Norway, CPT/Inf (2019) 1.

https://rm.coe.int/1680909713. 
Engbo HJ. (2019) Normalisering og isolation. In: Marte Rua and Peter Scharff Smith (red.) Isolasjon - et fengsel i fengselet. Oslo: Cappelen Damm Akademisk, 211-249.

Epp CR. (1998) The rights revolution: Lawyers, activists, and supreme courts in comparative perspective Chicago: University of Chicago Press. https://doi.org/10.7208/chicago/9780226772424.001.0001

Epp CR. (2008) Law as an instrument of social reform. The Oxford handbook of law and politics. https://doi.org/10.1093/oxfordhb/9780199208425.003.0034

Fettig A and Fathi DC. (2019) Loneliness Is a Destroyer of Humanity. Solitary Confinement: Effects, Practices, and Pathways toward Reform: 343. https://doi.org/10.1093/oso/9780190947927.003.0021

Gustafsson H and Vinthagen S. (2010) Rättens rörelser och rörelsernas rätt. Tidsskrift for Rettsvitenskap 123: 637-693.

Horn T. (2012) Er isolasjon av innsatte i politiarrest i strid med EMK artikkel 8? Tidsskrift for strafferett 12: 27-61.

Horn T. (2017) Fullstendig isolasjon ved risiko for bevisforspillelse: rettspolitiske vurderinger, Bergen: Fagbokforlaget.

Horn T. (2019) Isolasjon i politiarrest. I: Rua M and Smith PS (red.) Isolasjon - et fengsel i fengselet. Oslo: Cappelen Damm Akademisk, 81-108.

Kessing PV. (2019) Strafcelle - isolation af indsatte i danske fængsler. Juristen 101: 11.

Koch I, Sørensen B, Petersen M, et al. (2003) Isolation - en plet på det danske retssystem. I: Jørgen Jepsen and Jens Lyhne (red.) Retspolitiske utfordringer. Jubilæumsskrift for Dansk Retspolitisk Forening 1978-2003. København: Gads forlag, 311-337.

Langford M, Madsen M and Karlsson Schaffer J. (2019) The Scandinavian Rights Revolution: Courts, Rights and Legal Mobilization Since the 1970s. Rights and Legal Mobilization Since the 1970s (May 29, 2019).

https://doi.org/10.2139/ssrn.3395834

Lehoucq E and Taylor WK. (2020) Conceptualizing Legal Mobilization: How Should We Understand the Deployment of Legal Strategies? Law \& Social Inquiry 45: 166-193. https://doi.org/10.1017/Isi.2019.59

Lobel J. (2019) Litigation to End Indeterminate Solitary Confinement in California. I: Lobel J and Smith PS (red.) Solitary Confinement: Effects, Practices, and Pathways toward Reform. Oxford: Oxford University Press, 353. https://doi.org/10.1093/oso/9780190947927.003.0022

Lobel J and Smith PS. (2019a) Solitary Confinement-From Extreme Isolation to Prison Reform. I: Lobel J and Smith PS (red.) Solitary Confinement: Effects, Practices, and Pathways toward Reform. Oxford: Oxford University Press, 1.

https://doi.org/10.1093/oso/9780190947927.003.0001

Lobel J and Smith PS. (2019b) Solitary confinement: effects, practices, and pathways toward reform: Oxford University Press.

https://doi.org/10.1093/oso/9780190947927.001.0001

Mathiesen T. (2001) Retten i samfunnet: en innføring i rettssosiologi. Oslo: Pax.

Mathiesen T. (2011) Scandinavian exceptionalism in penal matters: Reality or wishful thinking?

McCann M. (2006) Law and social movements: Contemporary perspectives. Annu. Rev. Law Soc. Sci. 2: 17-38.

https://doi.org/10.1146/annurev.lawsocsci.2.081805.105917

Meyer DS and Minkoff DC. (2004) Conceptualizing Political Opportunity*. Social Forces 82: 1457-1492.

https://doi.org/10.1353/sof.2004.0082

Nasjonal institusjon for menneskerettigheter (2016) Melding for året 2015 fra Norges nasjonale institusjon for menneskerettigheter. Oslo, 34.

Parkes D. (2017) Solitary Confinement, Prisoner Litigation, and the Possibility of a Prison Abolitionist Lawyering Ethic. Canadian Journal of Law \& Society/La Revue Canadienne Droit et Société 32: 165-185. https://doi.org/10.1017/cls.2017.16 
Rua M and Smith PS. (2019a) Forord. I: Rua M and Smith PS (red.) Isolasjon. Et fengsel i fengselet. Oslo: Cappelen Damm Akademisk, 5-8.

Rua M and Smith PS. (2019b) Isolasjon - et fengsel i fengselet. I: Rua M and Scahrff Smith P (red.) Isolasjon. Et fengsel i fengselet. Oslo: Cappelen Damm Akademisk, 15-40.

Rua M, Smith PS, Horn T, and Nilsen JF, (2019) Isolasjon i skandinaviske fengsler - en oversikt. In: Rua M and Smith PS (red.) Isolasjon - et fengsel i fengselet. Oslo: Cappellen Damm Akademisk, 41-80.

Silbey SS and Ewick P. (2000) The rule of law-Sacred and Profane. Society 37: 49-56. https://doi.org/10.1007/s12115-000-1023-0

Silvilombudsmannen. (2019) Særskilt melding til Stortinget om isolasjon og mangel på menneskelig kontakt i norske fengsler. Oslo: Sivilombudsmannen.

Sivilombudsmannen. (2019) Besøksrapport. Oslo fengsel 19.-22. november 2018. Oslo: Sivilombudsmannen.

Sivilombudsmannen (2020) Bruk av sikkerhetsseng i norske fengsler. Temarapport 2020. Oslo: Sivilombudsmannen

Smith PS. (2008) Solitary confinement: An introduction to the Istanbul statement on the use and effects of solitary confinement. Torture 18: 56-62.

Smith PS. (2019) Solitary Confinement-Effects and Practices from the Nineteenth Century until Today. New York: Oxford University Press.

https://doi.org/10.1093/oso/9780190947927.003.0002

Smith PS and Koch I. (2019) Isolationens følgevirkninger - fra 1800-tallet til i dag. I: Rua M and Smith PS (red.) Isolasjon. Et fengsel i fengselet. Oslo: Cappelen Damm Akademisk, 109-140.

The Istanbul Statement. (2007) The Istanbul Statement on the Use and Effects of Solitary Confinement. Adapted on 9. December 2007 at the International Psychological Trauma Symposium, Istanbul.

The Mandela Rules. (2015) United Nations Standard Minimum Rules for the Treatment of Prisoners (the Mandela Rules): note / by the Secretariat, 29 September 2015, A/C.3/70/L.3. UN General Assembly.

Vanhala L. (2011) Legal Mobilization. Oxford Bibliographies. Oxford University Press. https://doi.org/10.1093/obo/9780199756223-0031

Vanhala L. (2012) Legal opportunity structures and the paradox of legal mobilization by the environmental movement in the UK. Law \& Society Review 46: 523-556.

https://doi.org/10.1111/j.1540-5893.2012.00505.x 